\title{
Some implications of lateritic weathering on geochemical prospecting - two Brazilian examples
}

\author{
J.C. PARISOT ${ }^{1}$, F. SOUBIES ${ }^{2}$, P. AUDRY ${ }^{3}$ and F. ESPOURTEILLE ${ }^{4}$ \\ 'Institut Français de Recherche Scientifique Pour le Développement en Coopération \\ (ORSTOM) UR 605, Lab. Pétro. Surface, Université de Poitiers, 86022 Poitiers Cedex, France \\ ${ }^{2}$ Institut Français de Recherche Scientifique Pour le Développement en Coopération \\ (ORSTOM) UR 605, Lab. Minéralogie et Cristallographie, Université de Toulouse, Allée Jules \\ Guesdes, 31000 Toulouse, France \\ "Institut Français de Recherche Scientifique Pour le Développement en Coopération \\ (ORSTOM) UR 202, Universidade Federal da Bahia, Salvador, Brazil \\ ${ }^{4}$ Mineraçao Boquira, Sao Paulo, Brazil
}

(Received January, 19, 1988; revised and accepted September 20, 1988)

\section{ABSTRACT}

Parisot, J.C., Soubies, F., Audry, P. and Espourteille, F., 1989. Some implications of lateritic weathering on geochemical prospecting - two Brazilian examples. In: S.E. Jenness et al. (Editors), Geochemical Exploration 1987. J. Geochem. Explor., 32: 133-147.

Geochemical and petrological studies were carried out in two Brazilian tropical areas. At the Cu prospect of 'Chapada Grande', under a wet savanna climate, the upper part of a lateritic profile with a partially eroded Fe crust was investigated. In the 'Vale do Paramirim', under a dry savanna climate, in an area of $\mathrm{Pb}-\mathrm{Zn}-(\mathrm{Cu})$ anomalies, lateritic soils with an underlying stone-line change laterally into sandy leached soils.

In both cases, there exists a good lithodependence upon the fresh parent rock of all the weathered material. At Chapada, there is a strong bonding between Fe-oxyhydroxides and $\mathrm{Cu}$. In soils above the crust, Fe-oxyhydroxides are mainly in the coarse granulometric fraction $(>1 \mathrm{~mm})$ in the form of Fe nodules whereas, in slopes soils without underlying crust, Fe-oxyhydroxides are mainly in the fine fraction $(<105 \mu \mathrm{m})$. In the Vale do Paramirim, the lateral leaching of Fe and clays is accompanied by a strong diminution of the $\mathrm{Pb}-\mathrm{Zn}$ - Cu content of the surface horizons and by an alteration of the correlations between these elements. In lateritic soils $\mathrm{Cu}$ and $\mathrm{Zn}$ are correlated but both elements present a very weak correlation with $\mathrm{Pb}$; on the other hand, in sandy soils the correlation between the three elements are identically weak.

With respect to geochemical prospecting, the study shows that sampling and data interpretation methods might be adapted to the soil type in the prospected environment. In both cases, the grouping of the data by classes of soils defined according to surface features (such as colour or the presence of coarse particules) is highly recommended before any statistical treatment is undertaken. 


\section{INTRODUCTION}

Many tropical regions are characterized by the presence of a thick, intensely weathered regolith. This has been formed by (1) an almost complete leaching of the alkaline and alkaline-earth elements and some silica, and (2) the relative accumulation of $\mathrm{Al}, \mathrm{Fe}$ and some $\mathrm{SiO}_{2}$. The result for the more weathered rocks is a simple mineralogical composition: neoformed kaolinite and $\mathrm{Fe}-\mathrm{Al}$ oxides and hydroxides (goethite, hematite, gibbsite) with, eventually, residual and/or neoformed quartz. Generally called laterites, these tropical weathering mantles exhibit a wide variety of vertical and lateral organizations controlled by the lithology and the bio-climatic and tectonic history.

In such formations, the geochemical expressions of the bed-rock is strongly controlled by the local conditions and mechanisms of the lateritic weathering. In the last ten years, knowledge of these problems has increased strongly with the publication of many regional studies on lateritic crusts or soils from West Africa (Boulet, 1974; Wackermann, 1975; Nahon, 1976, Leprun, 1979) and specific studies of elements such as Mn, Ni, Al and Fe (Grandin, 1973; Trescases, 1976; Boulangé, 1984) which form economic concentrations in lateritic profiles. Less numerous are studies dealing with the behavior of other metallic elements during lateritic weathering (Nalovic, 1977; Zeegers and Leprun, 1979; Butt and Smith, 1980; Laville-Timsit et al., 1982).

In the two Brazilian examples presented here, detailed studies of the weathering and pedogenesis, along slope sequences, have permitted a better understanding of the geochemical dispersion of $\mathrm{Cu}, \mathrm{Pb}$, and $\mathrm{Zn}$ and have led to exploration methods better adapted to some lateritic landscapes.

\section{LOCATION AND REGIONAL FEATURES}

\section{Chapada Grande}

The unmined Cu deposit of Chapada Grande is located about $250 \mathrm{~km}$ northwest of Brasilia (Fig. 1). This synsedimentary $\mathrm{Cu}$ mineralization, with chalcopyrite as the main $\mathrm{Cu}$ sulfide, is embedded in a metasedimentary formation that is dated as either Archean or early Proterozoic (Silva, 1981). This formation is the upper part of a greenstone belt (Ribeiro, 1978; Dani and Ribeiro, 1978; Saboia and Teixeira, 1980; Machado, 1981) and was metamorphosed to greenschist facies and in some places to amphibolitic facies. In the mineralized area, Silva (1981) marks five lithologic facies, depending on biotite, kyanite, sericite, feldspar and amphibole.

A Pliocene peneplain (King, 1956; Braun, 1970), caved into by a shallow drainage network (10-30 $\mathrm{m}$ deep), characterizes the landscape.

The climate is tropical with an average annual rainfall of $1800 \mathrm{~mm}$, half of 


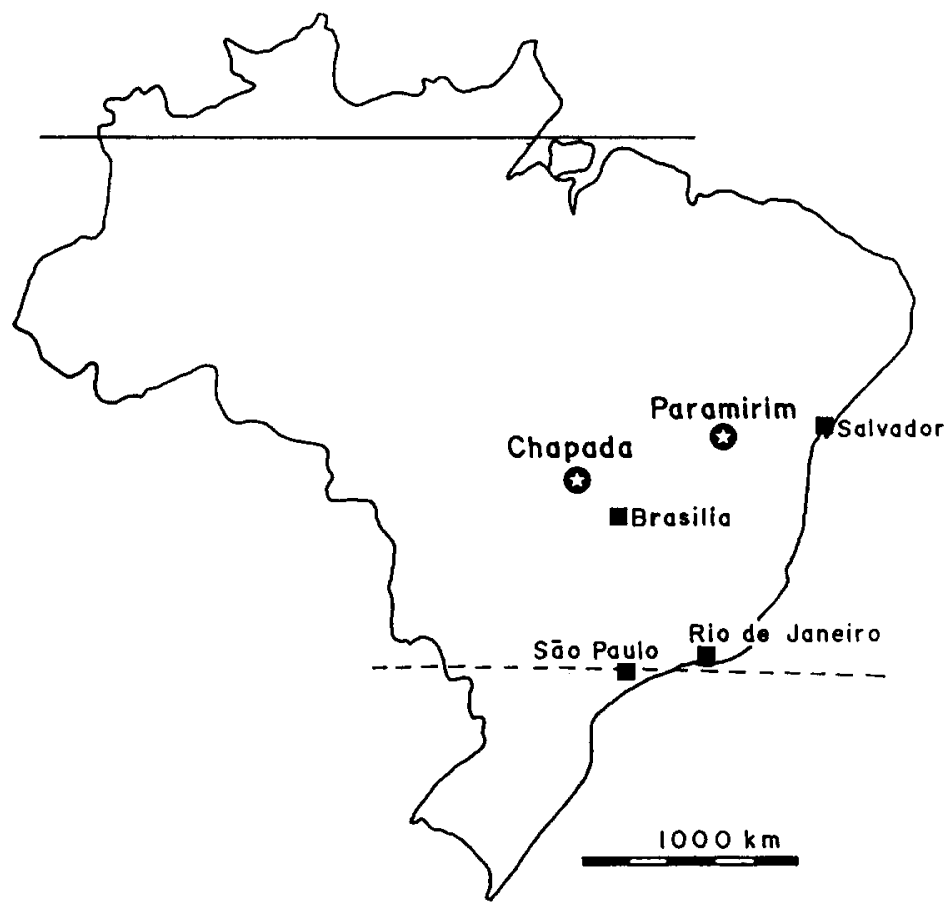

Fig. 1. Outline map of Brazil showing location of areas studied.

which falls between December and February. The vegetation is of the arbored savanna type (cerrado).

The weathering profile is very thick (exceeding $30 \mathrm{~m}$ ). At the base, the dark grey fresh-rock becomes lighter, and white stains appear. In this horizon, amphiboles and plagioclases are weathered into smectite. Higher up, the colour becomes red-brown, the parent-rock minerals are almost completely weathered, Fe oxides and kaolinite are the main secondary minerals. In this horizon, $15-25 \mathrm{~m}$ thick, the original parent-rock structure is still preserved (saprolite). A $0.5-1-\mathrm{m}$-thick horizon occurs 3-4 $\mathrm{m}$ under the surface, with the same mineralogical pattern as the preceding one, but the original parent-rock structure in it has been destroyed. Above this, a thin (0-1 m) Fe crust is developed which is massive at the base and nodular towards the top. This is covered by a thin brown soil where a quartz-kaolinite matrix coats several Fe nodules coming from the dismantling of the crust (Parisot and Melfi, 1982).

On the slopes and the valley floors the brown soil is directly in contact with the saprolite.

\section{Vale do Paramirim}

The Vale do Paramirim is located about $500 \mathrm{~km}$ west of Salvador and about $70 \mathrm{~km}$ southeast of the $\mathrm{Pb}-\mathrm{Zn}$ Boquira mine (Fig. 1). The area is a long basin 
$(50 \mathrm{~km} \times 150 \mathrm{~km})$ mainly underlain by early Proterozoic gneiss. Associated with this gneiss, the mineralized Boquira formation, consists of amphibolites, itabirites, quartzites and limestones (Espourteille and Fleischer, 1980; Carvalho, 1982).

The topography of the valley has a low relief and is formed by gently sloping plateaus, dissected by shallow, flat-floored dales, 5-10 m deep.

The region has a dry savanna climate with an annual rainfall of $700 \mathrm{~mm}$, concentrated during three months (November-January). There is only a temporary run-off during the wet season. A thorn shrud steppe (caatinga) is the main natural vegetation.

In this area the mantle of weathering is rather thin, rarely exceeding $4 \mathrm{~m}$, and two classes of soils are recognized whose distribution is widely independent of the lithology: red soils on small and gently sloping plateaus and leached, pale-colored soils near the drainage axis.

The bed-rock of the investigated slope sequence is a biotite gneiss. The red, powdery, $1.5-3-\mathrm{m}$-thick soil covering the plateau shows the following succession of horizons (Fig. 2): at the base, lying over the saprolite, a 10-80-cm-thick stone-line formed by centrimetric pebbles of quartz, weathered gneiss, and ferruginous nodules or concretions; above the stone-line, red and powdery $\mathrm{B}$ horizons, which show, in microscopic observation, a microaggregated structure where quartz and some feldspar relics are cemented by a micronodular, argillaceous and ferruginous matrix (kaolinite, hematite, goethite, and some illite); finally, at the top, a more sandy and greyer material where the micronodular structure disappears. Such soil, called 'latossolo' in Brazil, might be classed as 'Oxisol' or 'sol ferrallitique' in the U.S. and French classifications.

Downslope, in the direction of the drainage axis, the red soil gets paler and the sandy upper horizon thicker; at its bottom, hydromorphic spots appear as either ferruginous or mangano-ferruginous concretions, which sometimes may form a ferruginous crust (plinthitic horizons changing downward to ironstone).

Finally, in the vale, an essentially sandy and pale material caps the partially weathered or unweathered bedrock.

The petrologic study of this sequence showed:

(a) A first vertical evolution with autochthony of the stone-line and overlying materials, as indicated by the presence of lithorelics of the immediately underlying parent-rock in and over the stone-line. Internal eluviation working specifically at the level of the transition between the $\mathrm{B}$ and $\mathrm{C}$ horizons is generally observed and could explain the genesis of this stone-line.

(b) A second pedogenetic transformation with a continuous lateral passage of the red soils to the leached soils. Towards the drainage axis, there is a progressive degradation of the micronodular structure of the B horizon, together with an elimination of the argillic-ferruginous plasma. In this process, induced essentially by an intermittent hydromorphy, the bonding between $\mathrm{Fe}$ and clays is broken ('ferrolysis' mechanism; Brinkeman, 1970), and the released Fe, car- 


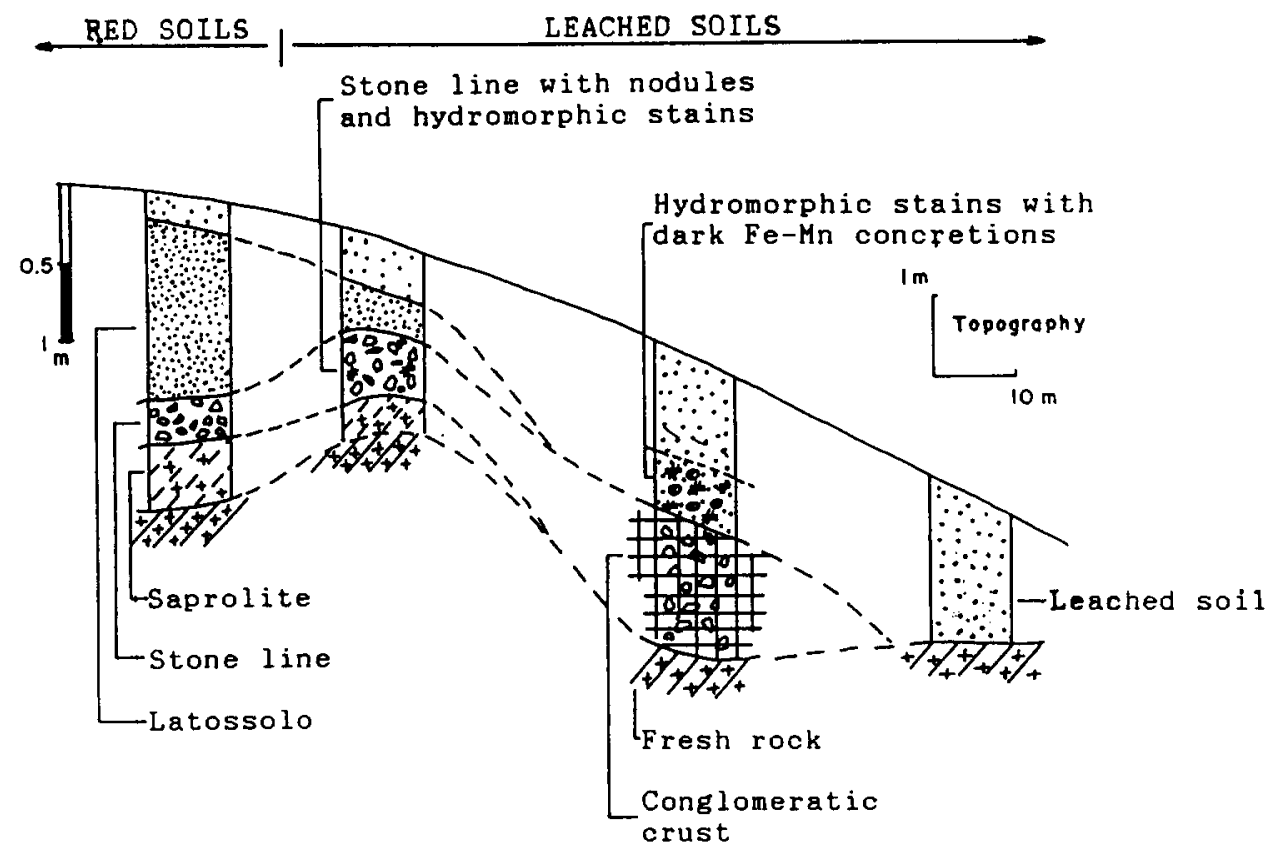

Fig. 2. Vale do Paramirim: longitudinal weathering profile on gneiss.

ried by lateral drainage, goes downward where it may finally precipitate with some Mn in Fe-Mn nodules or crusts (Soubies and Chauvel, 1985).

\section{BEHAVIOR OF METALLIC ELEMENTS DURING THE WEATHERING AND PEDOGENESIS}

\section{Chapada Grande}

Petrological and geochemical data showed that there exists a lithodependence of the weathered material upon the parent rock. Indeed, (1) kyanite lithorelics are found in the crust above the facies rich in kyanite, and (2) $\mathrm{Cu}$ content in the crust is anomalous above the mineralized area. Therefore, the crust is autochthonous.

Initial geochemical prospecting, using the minus $105 \mu \mathrm{m}$ soil fraction, gave anomalous values only in areas without lateritic crust; the crust seemed to impede the dispersion of $\mathrm{Cu}$.

Chemical analysis of rocks and soils of the weathered horizons shows from the bottom to the top a more or less regular decrease in Cu content (Fig. 3). We observe in the soil above the crust a strong decrease of the $\mathrm{Cu}$ content. This phenomenon is not observed in the soils without an underlying crust.

Granulometric separations were made on some samples of a profile with crust. 


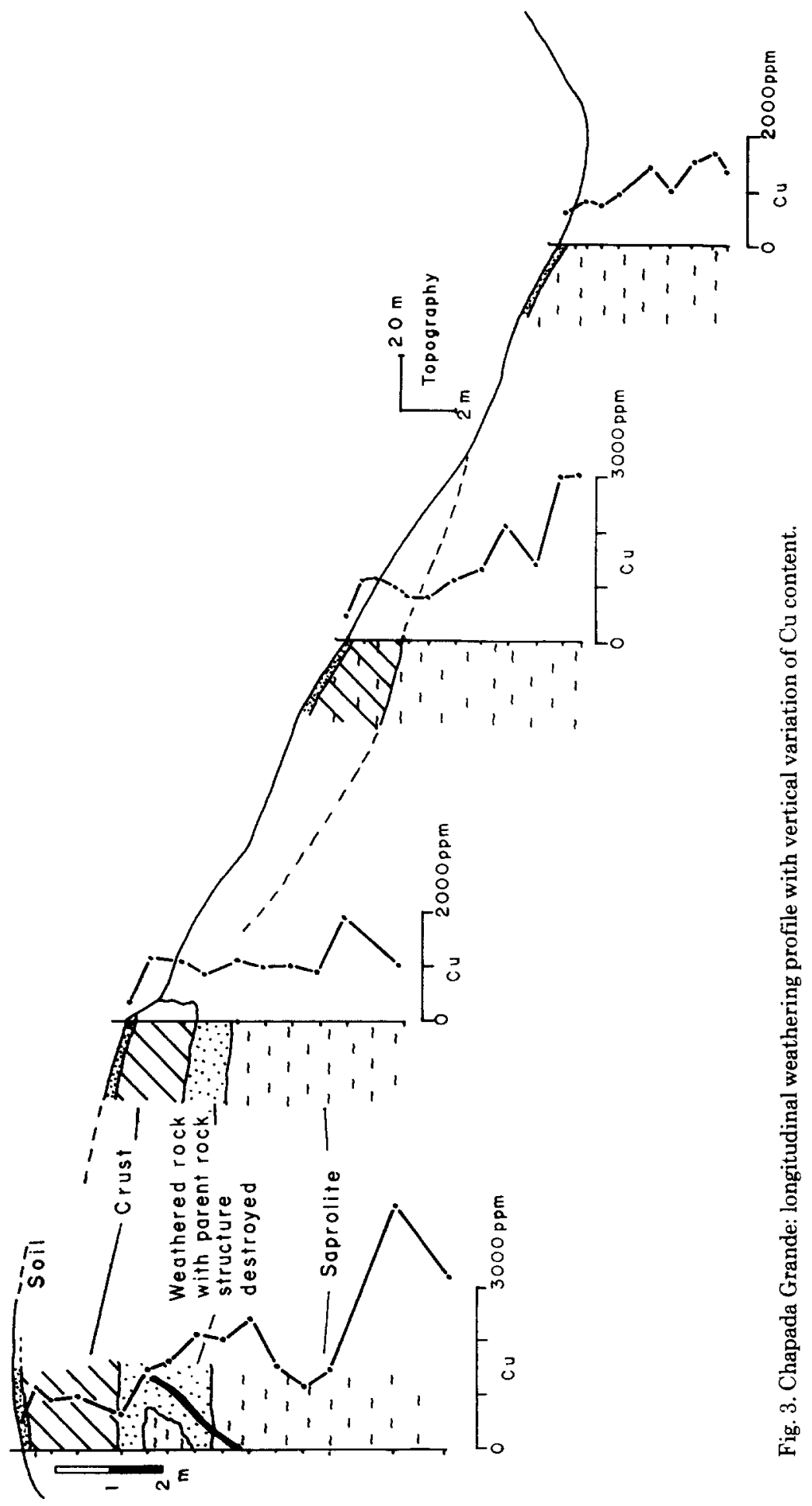


TABLE 1

Variation of $\mathrm{Cu}$ and $\mathrm{Fe}_{2} \mathrm{O}_{3}$ contents according to grain size in a lateritic profile at Chapada Grande. $\mathrm{Fe}_{2} \mathrm{O}_{3}$ content in \%, Cu content in ppm. R.T. = content in whole sample. $D=$ depth

\begin{tabular}{|c|c|c|c|c|c|c|c|c|}
\hline \multirow[t]{3}{*}{$\begin{array}{l}\text { Grain size } \\
\text { fraction } \\
(\mu \mathrm{m})\end{array}$} & \multirow{2}{*}{\multicolumn{2}{|c|}{ 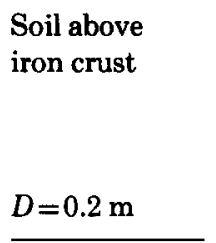 }} & \multirow{2}{*}{\multicolumn{2}{|c|}{$\begin{array}{l}\text { Weathered rock } \\
\text { with parent- } \\
\text { rock structure } \\
\text { destroyed } \\
D=1.5 \mathrm{~m}\end{array}$}} & \multicolumn{4}{|c|}{ Saprolite } \\
\hline & & & & & \multicolumn{2}{|c|}{$D=2 \mathrm{~m}$} & \multicolumn{2}{|c|}{$D=3 \mathrm{~m}$} \\
\hline & $\mathrm{Fe}_{2} \mathrm{O}_{3}$ & $\mathrm{Cu}$ & $\mathrm{Fe}_{2} \mathrm{O}_{3}$ & $\mathrm{Cu}$ & $\mathrm{Fe}_{2} \mathrm{O}_{3}$ & $\mathrm{Cu}$ & $\mathrm{Fe}_{2} \mathrm{O}_{3}$ & $\mathrm{Cu}$ \\
\hline$>1000$ & 25.74 & 900 & 23.96 & 1100 & 22.19 & 510 & 15.80 & 580 \\
\hline $1000-500$ & 22.19 & 685 & 18.28 & 900 & 9.41 & 630 & 8.88 & 535 \\
\hline $500-210$ & 9.23 & 305 & 13.31 & 680 & 5.82 & 475 & 4.81 & 465 \\
\hline $210-105$ & 4.00 & 314 & 5.90 & 728 & 4.25 & 594 & 4.36 & 633 \\
\hline$<105$ & 8.43 & 458 & 11.10 & 869 & 10.31 & 1036 & 9.12 & 894 \\
\hline R.T. & 9.76 & 300 & 10.83 & 655 & 9.94 & 885 & 8.95 & 755 \\
\hline
\end{tabular}

From the bottom to the top the $\mathrm{Cu}$ content decreases in the $<105 \mu \mathrm{m}$ fraction and increases in the $>1 \mathrm{~mm}$ fraction (Table 1 ).

Selective Fe oxide extractions have been made on the $<2 \mu \mathrm{m}$ fraction of some weathered samples, using oxalic acid and ammonium oxalate solution under U.V. light (Endredy, 1963; Segalen et al., 1972). Nine successive extractions were made on the same sample, with time interval of $30 \mathrm{~min}$. X-ray diffractions, before and after extractions, show the disappearance of goethite (the single Fe-mineral), though other minerals (kaolinite, muscovite) seem little or not at all touched by the reagent. Cumulative curves for $\mathrm{Cu}$ and $\mathrm{Fe}_{2} \mathrm{O}_{3}$ (Fig. 4 ) show the same kinetics of extraction. This suggests an association between extracted $\mathrm{Cu}$ and $\mathrm{Fe}_{2} \mathrm{O}_{3}$.

Microprobe analysis of ferruginous aggregates confirms the correlation between $\mathrm{Cu}$ and $\mathrm{Fe}_{2} \mathrm{O}_{3}$ (Fig. 5). The noncorrelation between $\mathrm{Cu}$ and $\mathrm{Al}_{2} \mathrm{O}_{3}$ indicates that there was no association between $\mathrm{Cu}$ and argillaceous minerals.

Therefore, it is logical to find in the soil above the crust, the higher $\mathrm{Cu}$ content in the coarse fraction $(>1 \mathrm{~mm})$, which is enriched with ferruginous nodules coming from the underlying crust. The fine fraction $(<105 \mu \mathrm{m})$ is essentially composed of quartz and kaolinite, which are unfavorable to the fixation of $\mathrm{Cu}$.

The slope and valley floor soils, which do not lie over an Fe crust, also contain ferruginous nodules, although in minor quantity compared to the plateau soils. Here, the fine fraction contains a variable proportion of smectite and $\mathrm{Fe}$ oxides, which are likely to fix Cu (Abd Elfattah and Wada, 1981; Warnant et al., 1981; McLaren et al., 1983). The origin of these nodules is not proved and 

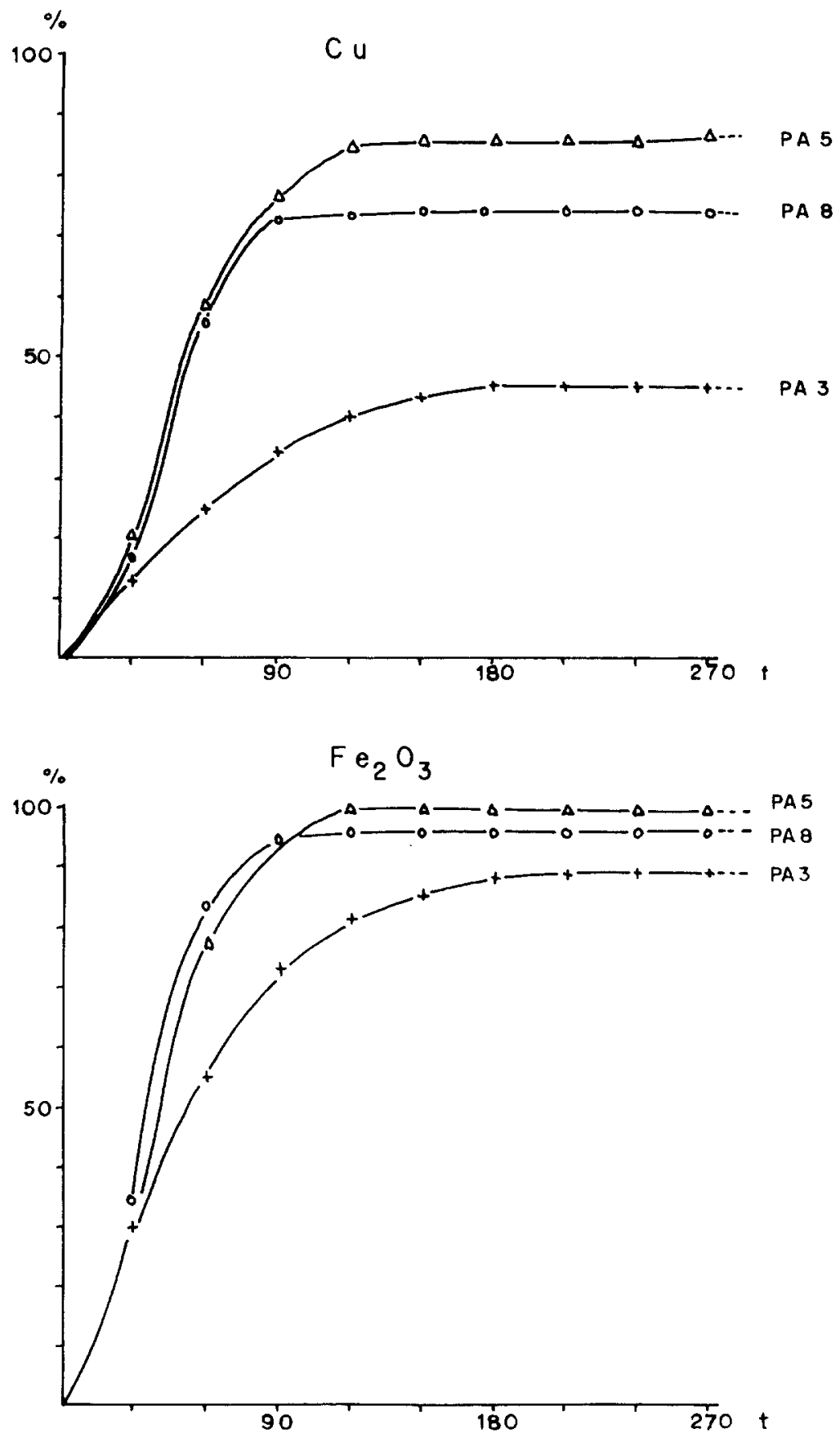

Fig. 4. Selective Fe-oxide extractions on $<2 \mu \mathrm{m}$ size fraction from Chapada Grande. Cumulative curves for $\mathrm{Cu}$ and $\mathrm{Fe}_{2} \mathrm{O}_{3}$. PA3 = iron crust; $\mathrm{PA} 5, \mathrm{PA} 8=$ saprolite. $y$-axis: $\% \mathrm{Cu}, \mathrm{Fe}_{2} \mathrm{O}_{3}$ extracted $(100 \%=$ content of element in the size fraction $) ; x$-axis: time in minutes. 

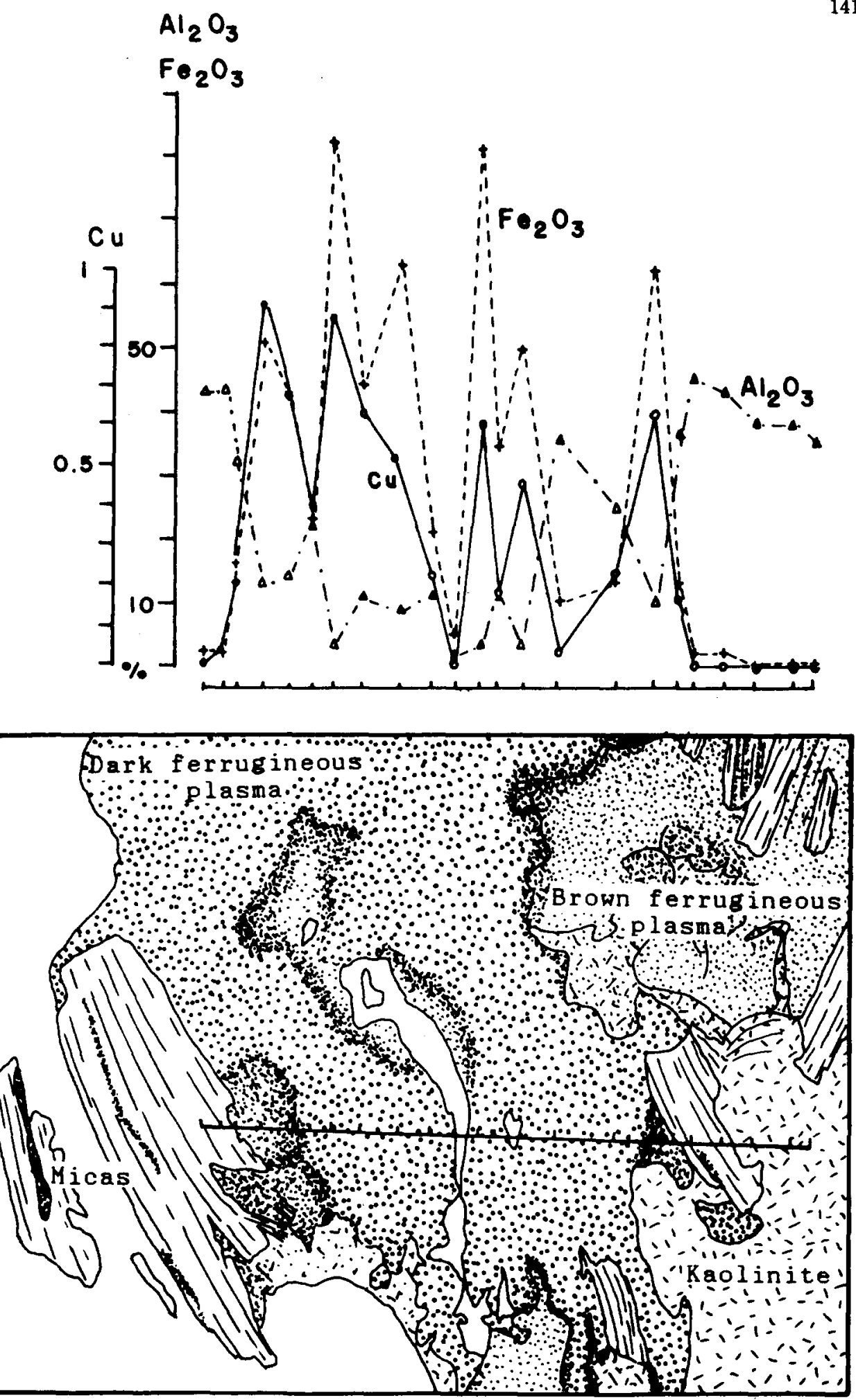

Fig. 5. Microprobe analysis of an argillic ferrugineous plasma showing the good correlation between $\mathrm{Fe}_{2} \mathrm{O}_{3}$ and $\mathrm{Cu}$. 
consequently, for geochemical prospecting, the fine fraction will be geochemically more representative of the parent rock.

\section{Vale do Paramirim}

In the upper horizons, at least, a strong leaching of $\mathrm{Cu}, \mathrm{Pb}$, and $\mathrm{Zn}$ go with the pedogenesis evolution (Table 2): the concentration of these elements is very low in the pale-coloured soil but is nearly the same as that of the parent rock (except partially leached $\mathrm{Zn}$ ) in the red powdery soil. Of interest as well, is the accumulation of $\mathrm{Pb}$ in the lower $\mathrm{Fe}-\mathrm{Mn}$ concretions or crust (where $\mathrm{Cu}$ and $\mathrm{Zn}$ are also partly trapped). This $\mathrm{Pb}$ concretionary accumulation is rather variable but may reach high levels (up to $1000 \mathrm{ppm}$ ), thus being a source of false anomalies when whole-soil analyses are conducted.

The principal geochemical fact, nevertheless, is that two very different and autochthonous geochemical haloes were derived from the same parent rock through this particular pedogenetic evolution: to a first halo, resulting from a ferrallitic pedogenesis and characterized by a higher regional $\mathrm{Cu}, \mathrm{Pb}$ and $\mathrm{Zn}$ background, succeeds over a period of time a second depressed halo linked with a posterior hydromorphic evolution. These phenomena, which affect almost any lithology (gneiss, amphibolites, micaceous quartzites, itabirites) of the prospected area, may be illustrated by some statistical data processing.

More than 10,000 samples of soils were collected in the Vale do Paramirim around potentially mineralized formations (amphibolites with high $\mathrm{Pb}-\mathrm{Zn}$ background). The $\leq 2 \mathrm{~mm}$ fraction of the samples, collected at the depth of 30 $\mathrm{cm}$ (top of the $\mathrm{B}_{2}$ horizon for the red soils and $\mathrm{A}_{2}$ horizon for the leached soils), was analyzed for $\mathrm{Pb}, \mathrm{Zn}$ and $\mathrm{Cu}$, and the data assembled in two groups according to their origin: red soils or leached soils. We tried to compute the intensity of the relations between $\mathrm{Pb}-\mathrm{Zn}, \mathrm{Zn}-\mathrm{Cu}$, and $\mathrm{Cu}-\mathrm{Pb}$ in each group. In order to avoid any previous assumption about the kind of relation existing between two elements $x$ and $y$, nonlinear correlation coefficients, $R_{x y}^{2}$ and $R_{y x}^{2}$, were com-

TABLE 2

$\mathrm{Cu}, \mathrm{Pb}, \mathrm{Zn}$ contents (in $\mathrm{ppm}$ ) in different materials of the Paramirim slope-sequence

\begin{tabular}{|c|c|c|c|}
\hline & $\mathrm{Cu}$ & $\mathrm{Zn}$ & $\mathrm{Pb}$ \\
\hline \multirow[t]{2}{*}{ Leached soil } & 2 & 3 & 3 \\
\hline & 45 & 19 & 11 \\
\hline \multirow[t]{2}{*}{ Red soil } & 34 & 29 & 16 \\
\hline & 34 & 26 & 21 \\
\hline \multirow{3}{*}{$\begin{array}{l}\text { Fe-Mn concretions } \\
\text { Iron crust } \\
\text { Bed rock }\end{array}$} & 41 & 21 & 104 \\
\hline & 25 & 14 & 96 \\
\hline & 41 & 122 & 20 \\
\hline
\end{tabular}




\section{TABLE 3}

Bonding intensity between elements taken two by two. $\left.I l=R_{x y}^{2} R_{y x}^{2}\right)^{1 / 2}$ in soils from Vale do Paramirim. $R_{x y}^{2}$ and $R_{y x}^{2}$ are all significants at the level $P=0.95$ (Audry and Soubies, 1983)

\begin{tabular}{lllll}
\hline Sample & $N$ & $I l(\mathrm{~Pb}-\mathrm{Zn})$ & $I l(\mathrm{Zn}-\mathrm{Cu})$ & $I l(\mathrm{Cu}-\mathrm{Pb})$ \\
\hline Total population & 10139 & 0.346 & 0.508 & 0.228 \\
Red soils & 2428 & 0.093 & 0.519 & 0.059 \\
Pale soils & 7046 & 0.378 & 0.392 & 0.221 \\
\hline
\end{tabular}

puted using the log-transformed values. For any pair of elements in each group, the values of $R_{x y}^{2}$ and $R_{y x}^{2}$ were always very close, so that the intensity of the bonding between the two elements might be represented by the geometrical value: $I l=\left(R_{x y}^{2} R_{y x}^{2}\right)^{1 / 2}$. As is shown in Table 3 , for the red soils, $\mathrm{Cu}$ and $\mathrm{Zn}$ are clearly intercorrelated, but both elements present a very weak correlation with $\mathrm{Pb}$; on the other hand, in the leached soils, the correlations between the three elements are almost identically weak.

These results, which show clearly the great differences existing between the two groups of soils, seem in good agreement with the literature data about the supergene behavior of these elements. In the red soils, in an oxidizing and slightly acid environment ( $\mathrm{pH}$ 5-6), $\mathrm{Cu}$ and $\mathrm{Zn}$ may move moderately and be absorbed by the phyllosilicates (Mosser, 1980) or the authigenic Fe oxideshydroxides; but the tendency is for $\mathrm{Pb}$ to form insoluble compounds with various anions such as $\mathrm{CO}_{3}^{2-}, \mathrm{PO}_{4}^{3-}$, and $\mathrm{SO}_{4}^{2-}$. (Laville-Timsit et al., 1983) or, according to local conditions, to coprecipitate with Mn oxides. A correlation between $\mathrm{Cu}$ and $\mathrm{Zn}$ was thus to be expected, but not necessarily between $\mathrm{Pb}$ and these elements. In the leached soils, which are the product of the hydromorphic transformation of the red soil, $\mathrm{Cu}, \mathrm{Pb}$ and $\mathrm{Zn}$ signals are essentially carried by small residual fragments of argillic-ferruginous plasma for $\mathrm{Cu}$ and $\mathrm{Zn}$, and small $\mathrm{Fe}-\mathrm{Mn}$ concretions for $\mathrm{Pb}$. These fragments and concretions are dispersed in a variable manner through the soil materials. A weak correlation between the three elements might so appear.

\section{APPLICATION TO GEOCHEMICAL PROSPECTING}

Finally, in the Chapada Grande district as in the Paramirim valley, weathering and pedogenesis resulted in the formation, widely independent of the lithology, of two populations of soils where the geochemical behavior of the elements is quite different: red or leached soils in the Paramirim valley, with or without underlying Fe crust soils in the Chapada Grande district. Each population must be treated differently during geochemical prospecting.

In Chapada, the association of $\mathrm{Cu}$ with $\mathrm{Fe}$ oxides is the preponderant factor. Some authors, who also noted this association in the weathering covers in tem- 
TABLE 4

Variation of Cu content in some soils of Chapada Grande

\begin{tabular}{lrrlcr}
\hline Size fraction & \multicolumn{2}{l}{ Soils with iron crust } & \multicolumn{3}{l}{ Soils without iron crust } \\
\hline$>2 \mathrm{~mm}$ & 1030 & 1025 & 550 & 663 & 833 \\
$<2 \mathrm{~mm}$ & 475 & 413 & 500 & 513 & 758 \\
Total sample & 519 & 450 & 537 & 525 & 790 \\
\hline
\end{tabular}

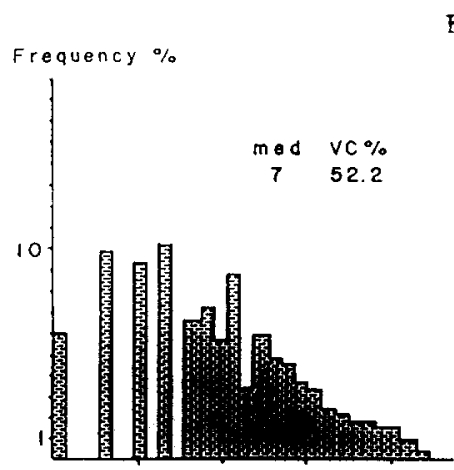

RED AND LEACHED SOILS

$N=10139$
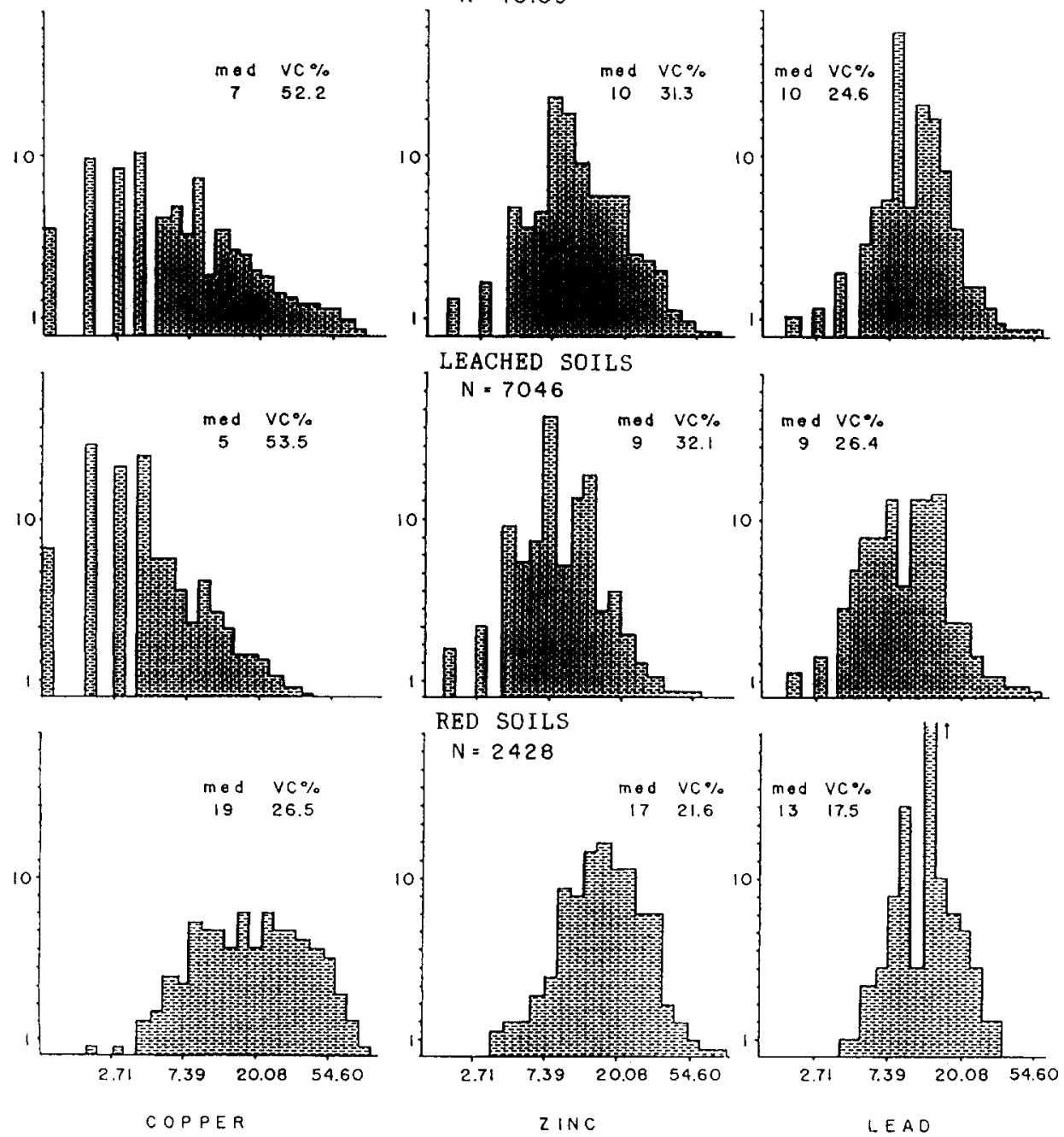

Fig. 6. Histograms for $\mathrm{Cu}, \mathrm{Pb}, \mathrm{Zn}$ contents (in ppm) in the different types of soils. med=average value: $\mathrm{VC} \%=$ variation coefficient. 
perate areas, recommend either the analyses of the paramagnetic fractions (Wilhelm et al., 1978) or solutions of selectively extracted Fe oxides (Warnant et al., 1981). In lateritic areas, however, and for the overlying Fe crust soils, the Fe oxides are naturally aggregated in autochthonous nodules; for this kind of cover, consequently, the coarse granulometric fraction $(>1 \mathrm{~mm})$ will give a better geochemical halo than the commonly used fine fraction $(<105 \mu \mathrm{m})$. Similar conclusions have been drawn by Smith and Perdrix (1983) and Zeegers and Leprun (1979). But in the Chapada area, and probably in other Brazilian areas partially covered by lateritic crust, on slopes and drainage axis areas, nodules are certainly allochthonous, and the fine fraction is, on the contrary, recommendable (Table 4).

In the Paramirim valley, the sporadic presence of Fe-Mn concretions, which concentrate some elements, leads up to the preference of using the fine granulometric fractions. A systematic study of this problem was not, however, undertaken; only a separate statistical treatment of each population of soil was carried out. There is a distinct difference between the $\mathrm{Cu}, \mathrm{Pb}, \mathrm{Zn}$ histograms of the leached soils and those of the red soils (Fig. 6). Anomalous values in the leached soils may correspond to middle or low values in the red soils and does not appear in the histograms for all samples. Some indices of mineralization occurring in the leached soils areas were detected in this manner.

These two Brazilian examples show the importance of the 'pedogenetic story' in the secondary dispersion of some elements. In tropical areas, a good knowledge of the factors that control the pedologic evolution seems very important to improve the value of any geochemical prospecting.

\section{ACKNOWLEDGMENTS}

The authors would like to thank Mineraçao Boquira and Mineraçao Serra do Lest for their help in the field. Acknowledgements are also due to Conselho Nacional de Pesquisa (CNPq) and Fondaçao de Amparo para Pesquisa no Estado de Sao Paulo (FAPESP) for financial support.

\section{REFERENCES}

Abd-Elfattah, A. and Wada, K., 1981. Adsorption of lead, copper, zinc, cobalt and cadmium by soils that differ in cation-exchange materials. J. Soil Sci., 32: 271-283.

Audry, P. and Soubies, F., 1983. Estudo da imagem geoquimica das rochas matrizes nas coberturas pedologicas complexas do Vale do Paramirim (Bahia). Applicaçao a prospecçao geoquimica do chumbo e do zinco. Rep., Conselho Nacional de Pesquisa, Brasilia, Brazil, 93 pp. (unpubl.).

Boulangé, B., 1984. Les formations bauxitiques latéritiques de côte d'Ivoire. Les facies, leur transformation, leur distribution et l'évolution du modelé. Trav. Doc. l'ORSTOM, 175, 363 pp.

Boulet, R., 1974. Toposéquences de sols tropicaux en Haute-Volta. Equilibre et déséquilibre pédobioclimatique. Mém. ORSTOM, 85, $272 \mathrm{pp}$.

Braun, O.P.G., 1970. Contribuiçao a geomorfologia do Brasil. Rev. Bras. Geogr., 3 (32): 3-39. 
Brinkeman, R., 1970. Ferrolysis, a hydromorphic soil-forming process. Geoderma, 3: 199-206.

Butt, C.R.M. and Smith, R.E., 1980. Conceptual Models in Exploration Geochemistry. Australia. J. Geochem. Explor., $12(2 / 3), 360$ pp.

Carvalho, I.G., 1982. Geology of the Pb-Zn district of Boquira-Bahia state - Brazil. Ve Congr. Latino Americano de Geologia, 11: 611-628.

Dani, J.C.M. and Ribeiro, C.C., 1978. Caracterizaçao da sequencia vulcano-sedimentar de Pilar de Goias e de Guarinos, GO. XXXe Congr. Brasileiro de Geologia, Recife, pp. 582-586.

Endredy, A.S. de, 1963. Estimation of free iron oxides in soils and clays by a photolytic method. Clay Mineral. Bull., 29 (5): 209-217.

Espourteille, F. and Fleischer, R., 1980. A mina de Boquira. In: Secretaria das Minas e Energia (Editor), Geologia e Recursos Minerais do Estado da Bahia, 3. Salvador, Brazil. pp. 104-124.

Grandin, G., 1973. Aplanissements Cuirassés et Enrichissement des Gisements de Manganèse dans quelques Régions d'Afrique de l'Ouest. Mém. ORSTOM, 82, 275 pp.

King, L.E., 1956. A geomorfologia do Brasil central. Rev. Bras. Geogr., 2(18): 147-265.

Laville-Timsit, L., Leleu, M., Sarcia, C. and Zeegers, H., 1982. Geochemical dispersion of $\mathrm{Pb}$ and $\mathrm{Zn}$ in ferralitic environment: an example in French Guyana. In: A.J. Melfi and A. Carvalho (Editor), Lateritisation Processes. IInd Int. Seminar on Lateritic Processes. Sao Paulo, Brazil, pp. 433-442.

Leprun, J.C., 1979. Some principal features of iron crust in dry Western Africa. In: Lateritisation Processes. 1st Int. Seminar on Lateritic Processes, Trivandrum, India, pp. 144-153.

Machado, E.G., 1981. Novas consideraçoes e intergraçao geologica na regiao de Pliar-Crixas/Nova Rosa-Parangaba. 1st Simp. Geol. Centro Ouest, Goiana, Brazil, pp. 300-318.

McLaren, R.G., Williams, J.G. and Swift, R.S., 1983. Some observations on the description and distribution behaviour of copper with soil components. J. Soil Sci., 34: 325-331.

Mosser, C., 1980. Etude géochimique de quelques éléments-traces dans les argiles des altérations et des sédiments. Thesis Sci., Strasbourg, France, 222 pp.

Nahon, D., 1976. Cuirasses ferrugineuses et encroutements calcaires du Sénégal occidental et en Mauritanie. Systèmes Evolutifs: Géochimie, Structures, Relais et Coexistence. Mém. Sci. Géol., Strasbourg, 44, $232 \mathrm{pp}$.

Nalovic, L., 1977. Recherches géochimiques sur les éléments de transition dans les sols. Etude expérimentale de l'influence des éléments-traces sur le comportement du fer et l'évolution des composés ferriques au cours de la pédognèse. Trav. Doc. ORSTOM, 66, 235 pp.

Parisot, J.C. and Melfi, A.J., 1982. Lateritic alteration of metasedimentary rocks with copper sulfide mineralization in central Brazil. In: A.J. Melfi and A. Carvalho (Editors), Lateritisation Processes. Ind Int. Seminar on Lateritic Processes, Sao Paulo, Brazil, pp. 185-195.

Ribeiro Filho, W., 1978. Projeto geologia da regiao Pilar-Nova Rosa. Unpublished. Final report, Departamento Nacional de Produçao Mineral \& Companhia de Pesquisas de Recursos Minerais, Brazil, 144 pp.

Saboia, L.A. and Teixeira, N.A., 1980. Lavas ultrabasicas da unidade basal do greenstone belt de Crixas (GO): uma nova classe de rochas ultrabasicas do estado de Goias. Rev. Bras. Geociênc., $10(1): 28-42$.

Segalen, P., Parrot, J.F., Ichterz, M.N., Verdoni, P., 1972. Effet de méthodes d'extraction cinétique utilisées pour la détermination des produits ferrugineux sur quelques minéraux purs. Cah. ORSTOM, Sér. Pédol., 10(3): 251-271.

Silva, J.A., 1981. Jazida de cobre de Chapada, Nova Rosa, Goias. In: Os Principais Depositos Minerais da Regiao Centro-Oeste, Departamento Nacional de Pesquisa Mineral, Goiânia, Brazil: $50-64$.

Smith, R.E. and Perdrix, J.L., 1983. Pisolitic laterite geochemistry in the Golden Grove massive sulfide district, Western Australia. J. Geochem. Expor., 18: 131-164.

Soubies, F. and Chauvel, A., 1985. Présentation de quelques systèmes de sols observés au Brésil. Cah. ORSTOM, Sér. Pédol., 21 (4): 237-251. 
Trescases, J.J., 1976. L'évolution géochimique supergène des roches ultrabasiques en zone tropicale. Formation des gisements nickélifêres (Nouvelle Calédonie). Mém. ORSTOM, 78, 259 pp.

Wackermann, J.M., 1975. L'altération des massifs cristallins basiques en zone tropicale semihumide. Etude minéralogique et géochimique des arènes du Sénégal oriental. Conséquences pour la cartographie et la prospection. Thesis of Sci., Strasbourg, France, 373 pp. (unpubl.).

Warnant, P., Martin, H. and Herbillon, A.J., 1981. Kinetics of the selective extraction of iron oxides in geochemical samples. Association between $\mathrm{Fe}$ and $\mathrm{Cu}$ in acid brown soil. J. Geochem. Explor., 15(1-3): 635-644.

Wilhelm, E., Laville-Timsit, L. and Leleu, M., 1978. Behaviour of base methods around ore deposits: application to geochemical prospecting in temperate climates. Proc. 7th Int. Geochemical Exploration Symposium, Colorado, pp. 185-199.

Zeegers, H. and Leprun, J.C., 1979. Evolution des concepts en altérologie tropicale et conséquences potentielles pour la prospection géochimique en Afrique occidentale Soudano-Sahélienne. Bull. Bur. Rech. Géol. Minière Ser. II, 2: 229-239. 